\title{
The introduction of the Linnaean classification of nature in Portugal
}

\section{Palmira Fontes da Costa}

\section{Introduction}

In Systema Naturae, published in 1735, Linnaeus first presented his system of classification of the natural world to the international community. By 1770 , the work was in its thirteenth edition. Some idea of its impact on a Portuguese reader from the period can be inferred from an annotated copy now held at the Portuguese National Library (Linnaeus 1793). On the one hand, the copious remarks of the anonymous reader testify to his/her eagerness to access the Linnaean language of nature. On the other hand, they reveal the reader's persistent difficulties in understanding Latin.

What kind of efforts were made by Portuguese naturalists to make the Linnaean system of classification more accessible to students and to the general enthusiast for natural history? What was the impact of the Linnaean system in the development of Portuguese botanical science? And what was the influence of presentations of the Linnaean classification in works that crossed the boundaries between science and literature?

In this paper I examine the contribution of the Linnaean method of classification to the reshaping of botanical education in Portugal. Next, I show how the publication of a Portuguese flora using the Linnaean system of classification was associated with important national aims. I also examine the importance of including illustrations in Portuguese works that first presented the Portuguese flora according to the new principles of classification. I then discuss the introduction of the Linnaean system of classification in works dealing with the flora of the Portuguese Empire and look at some of the difficulties faced by their authors. Finally, I focus on another genre of literature which contributed to the diffusion of the Linnaean ideas of classification, the poetic work of the Marquesa de Alorna's Botanical Recreations. In this way, I demonstrate the variety of works and places in which the Linnaean language of nature was influential not only in Portugal, but also in the Portuguese Empire. 


\section{Classification and botanical instruction}

The Linnaean programme for the classification of nature entered the Portuguese teaching system as a result of the reform of the University of Coimbra launched in 1772 by the Marquis of Pombal (1699-1782), then the Prime Minister of King José I (1714-1777) (Carvalho 2001: 423-484). The reform contemplated the creation of a chair in natural history which, for the first time, enabled Portuguese naturalists to be educated at university level. In the study of botany, it became obligatory to follow Linnaeus's Philosophia Botanica (1751), to which was added the thirteenth edition of Linnaeus's Systema Naturae published by the University of Coimbra in 1793. The professor invited to occupy the new chair was Domenico Vandelli (1732-1815), a naturalist born and taught in Padua, where he completed his university education in medicine and natural history (Melli 1966). Vandelli had insight into the ideas of Linnaeus (17071778) not only through his works, but also from correspondence maintained with him for several years (1759-1773). ${ }^{1}$ The correspondence indicates that, besides the exchange of news relevant to natural history, he was influential in sending Linnaeus various specimens, in particular from Brazil and other parts of the Portuguese Empire.

In accordance with the aims promoted by the new university's statutes, Vandelli founded the Natural History Cabinet in 1772 and collaborated in the creation of the University Botanical Garden the same year (Carvalho 1987: 4462 ). Both institutions were founded with the aim of having a prominent role in the practical instruction of students enrolled on the course in natural history. Significantly, the Botanical Garden was organized according to the Linnaean principles of classification.

During this period, there was a huge lack of botanical works. The first attempts to give a Portuguese shape to this area of knowledge are to be found in two books, both published in 1788: Vandelli's Dictionary of the technical terms of Natural History extracted from the works of Linnaeus (Vandelli 1788) and Félix Avelar Brotero's (1744-1828) Compendium of Botany (Brotero 1788). If Vandelli's work is confined to a translation of some of the most frequently used botanical terms, Brotero's aimed to provide a complete introduction to botany, also including an extensive dictionary of names. In fact, this can be considered the first Portuguese treatise on the subject. Its relevance resides not only in its pioneering role but also in its intrinsic value, which was acknowledged by some

1. A summary of the letters exchanged between Linnaeus and Vandelli can be found at the Linnaean Correspondence Project (http://linnaeus.c18.net/Letters/letter_list. php). 
of Brotero's colleagues, such as the German botanist Heinrich Friedrich Link (1767-1851) (Link [1801] 2005: 185). ${ }^{2}$

Brotero was not a university-trained naturalist. During his youth, he acquired a profound knowledge of classical languages, something that would later be of paramount importance in his career as a naturalist. ${ }^{3}$ In 1778, at the age of 34 , he fled to Paris to escape political persecution. It was here that he acquired his education in and enthusiasm for natural history. He attended public courses on the subject by Antoine Laurent de Jussieu (1748-1836), Jean-Baptiste Lamarck (1744-1829) and Jacques-Christophe Valmont de Bomare (1731-1807) (Fernandes 1988:3). Brotero wrote his Compendium in this city. Being aware that the statutes of the University of Coimbra required the preparation of a textbook for the new courses, he probably hoped that the publication of his Compendium of Botany would help him obtain a chair at the university. Indeed, the year following its publication, Brotero returned to Portugal to teach natural history and agriculture at the University of Coimbra. A few years later, in 1791, he was elected Director of the Botanical Garden of the University and, in 1811, of the Ajuda Palace Gardens and Museum in Lisbon.

In his Compendium of Botany, Brotero recognizes the educational value of the Linnaean system, as well as its widespread acceptance in Europe. This, and the fact that it was the system that had been adopted by the University of Coimbra, are for him sufficient reasons to dedicate the second volume of his treatise to its presentation. To help explain it, he uses illustrations taken from Linnaeus and other botanists.

However, unlike Vandelli, Brotero is not a strict follower of Linnaeus and expresses his awareness of the limitations and disadvantages of the Linnaean system. Accordingly, he also presents the views of other famous botanists on the subject in order that "the reader is made aware not only of its advantages, but also its limitations, and therefore can attribute to it its real value" (Brotero 1788: vii).

2. In his Notes on a Voyage through Portugal, Link stated that Brotero's Compendium of Botany "shows as much knowledge as all our German introductions and more skill than these in understanding and embarking on new perspectives" (Link [1801] 2005: 185).

3. On the life and work of Brotero, see Castel-Branco 2004. 


\section{Classification and national identity}

The Portuguese reception of Linnaeus's system would not have reached its full significance if it had not had an impact on the very practice of botany. In fact, one of the most frequent topics in the correspondence between Linnaeus and Vandelli is precisely the urgent need for a compilation and description of the Portuguese flora. ${ }^{4}$ Vandelli's Florae Lusitanicae et Brasiliensis specimen (1788) did not satisfy this desideratum, since it included only a few species and the descriptions were minimal. Vandelli was also the author of Viridarium Grisley Lusitanicum (1789). However, this work was considered by several of Vandelli's contemporaries to have limited value. ${ }^{5} \mathrm{In}$ fact, it is no more than a list of the species previously described by Grisley with the corresponding Linnaean terminology.

The task of publishing a Portuguese flora was to be undertaken by Brotero in 1804, and it was not the result of his efforts alone. Indeed, the publication of such a work was taken to be a matter of national importance. The government itself, and particularly the minister D. Rodrigo de Sousa Coutinho, encouraged Brotero and provided him with funds and a special licence needed for the herborizations that were to be conducted in various parts of Portugal. In addition, the Portuguese government bore the costs of publication. The fact that two other foreign naturalists, the Germans Comte d'Hoffmannsegg (17661819) and Heinrich-Friedrich Link (1766-1819), were pursuing a similar goal put nationalist pride at stake, and Brotero felt that he was under pressure to finish the project as soon as possible.

Flora Lusitanica (1804) presents a clear and meticulous description of 1,885 species from Portugal, of which more than one hundred were described for the first time. The author uses a classificatory method based on the Linnaean sexual system, but reduces the original 23 classes to 11, making it simpler and adapting it to the classification of the Portuguese flora (Palhinha 1944: 75-93). In comparison with natural systems of classification, the Linnaean method had the advantage of taking into account a relatively small number of identificatory traits, therefore enabling quick and easy identification of plants already known or not yet described. From this point of view, it had practical advantages as compared with natural methods of classification and it can be said that it was its use that enabled Brotero to finish his Flora in a relatively short period of time (10 years).

4. See letters from Linnaeus to Vandelli dated 12 February 1765, 15 July 1767, 13 May 1769, and 7 January 1770 (http://linnaeus.c18.net/Letters/letter_list.php).

5. Brotero describes Vandelli's Viridarium Grisley Lusitanicum as a poor work and of no use (Brotero 1804: iv-v). 
It should also be noted that Brotero was aware of the slow progress in the development of natural systems of classification and that, like artificial systems, they were not without imperfections. Another element to take into account is that the establishment of natural systems would only have been possible by means of the most complete study of all the applicable classificatory groups and, since Portugal was relatively small, several of them would have been impossible to find and others would have had few representatives (Fernandes 1986: 890).

A work on natural history published in such haste was bound to have its shortcomings. The most obvious one was the absence of illustrations, something that was needed particularly for the new plants described. ${ }^{6}$ In addition, the work left out a number of native plants (Luisier 1944: 149). Unlike Linnaeus, for whom illustrations had an insignificant role in the development of natural historical knowledge, Brotero credited visual representations with a vital role in the practice and diffusion of natural history (Brotero 1788: 1xvi).

In fact, as Cristina Castel-Branco has remarked, "Brotero was forced eternally to atone for the sin of a flora written in such haste, which obliged him not to include illustrations and to leave out so many plants, although he knew they should have been included in his first work" (Castel-Branco 2004: 232). Brotero's later work, Phytographia Lusitania Selectior, in two volumes (1826 and 1827), was intended precisely to fill this gap. The work presents 181 copperengraved illustrations of species native to Portugal, some of them not previously described by Brotero. ${ }^{7}$

In spite of all the patriotic effort put into the publication of Brotero's Flora Lusitanica, the work seems to have enjoyed greater success outside Portugal. Letters to the author from the Portuguese naturalist Correia da Serra, who was at the time living in Paris, provide evidence of the general acclaim given to the publication by foreign colleagues. ${ }^{8}$ Brotero did not enjoy an easy relationship with most of his colleagues from the University of Coimbra, including Domingos Vandelli, and this certainly had a negative impact on the reception of his work in Portugal. ${ }^{9}$ Indeed, we might say that Brotero's contribution to

6. The absence of illustrations had nothing to do with the significant costs involved in their production, since such expenses had been previously assured to Brotero by the minister D. Rodrigo de Sousa Coutinho (Fernandes 1988:6).

7. Some of the illustrations were engraved by the artist F. De Queiroz and others by artists from the publishing house Arco do Cego (Fernandes 1988: 9).

8. Correia da Serra was probably the main figure responsible for the diffusion of the work abroad. He was responsible for advertising Flora Lusitanica in the Archives Littéraires, the Journal de Physique and the Magazin Encyclopedique (Simões, Diogo, and Carneiro 2006: 102).

9. By this time Vandelli was already using the Portuguese version of his first name. 
the development of Portuguese botany was only fully acknowledged in the late nineteenth century. ${ }^{10}$

\section{Classification and empire}

In his correspondence with Vandelli, Linnaeus remarked on the advantageous opportunities offered by the Portuguese Empire for the pursuit of natural historical research. He specifically wished the Portuguese to become aware of the natural richness of their realms, something that would arouse the envy of others who did not have exotic provinces. ${ }^{11}$ To what extent were these opportunities seized by the Portuguese naturalists of the period?

Vandelli had an important role in the creation in 1768 of the Ajuda Palace Museum and Gardens in Lisbon, institutions that were focal points for Portuguese overseas collecting activity (Brigola 2003). Later on, during the reign of Queen Maria I (1777-1792), the Royal Academy of Sciences in Lisbon was founded in 1779. This institution was of paramount importance in guiding scientific research conducted overseas, as well as in promoting discussion and the publication of numerous memoirs on the subject (Cardoso 1990-1991: xviixxxiii; Oswaldo 1997). The anonymous instruction manual for correspondents of the Academy of Sciences from overseas, in which Vandelli most probably collaborated, does not make any specific reference to the Linnaean system of classification. It simply notes that "the indigenous name should be given, as well as the foreign name of the species, together with the name most often used by naturalists" (Real Academia das Ciências de Lisboa 1781: 39).

In spite of Linnaeus's advice to Vandelli, his Florae Lusitanicae et Brasiliensis specimen (1788) is a very incomplete work that presents only a limited number of species from the Brazilian flora, accompanied by detailed descriptions. It is true that Vandelli wrote many memoirs concerning the natural history of Brazil, but only in some of them are the names of living things presented according to the Linnaean system of classification. ${ }^{12}$ Indeed, for him, "the study of natural history was not mere classification. It included observations, experi-

10. It was mainly the naturalist Júlio Augusto Henriques who contributed to this recognition, after his election to the chair of botany at the University of Coimbra (Henriques 1889).

11. Letter from Linnaeus to Vandelli dated 12 February 1765 (http://linnaeus.c18.net/ Letters/letter_list.php).

12. Several of Vandelli's memoirs were published by the Royal Academy of Sciences in Lisbon (Cardoso ed. 1994). 
ments to discover connections and the order of nature, its economy and policy, and the formation of the earth and the transformations it went through as well as the advantages to be gained from natural productions" (quoted in Cardoso (ed.) 2003: 13). As José Luís Cardoso has shown, Vandelli was especially Linnaean in his strong views on the close relationship between natural history and political economy (Cardoso 2003). Like Linnaeus, he considered a mastery of the products of nature the true source of economic progress.

Educational and economic reforms were closely linked, and some of the first naturalists educated at the University of Coimbra were employed by the Portuguese state on scientific voyages to the overseas territories to define a strategy for the optimal allocation of available resources (Simon 1983; Lopes, Silva, Figueirôa, and Pinheiro 2005). Vandelli believed that the international success of these trips could only be guaranteed through the use of the Linnaean system of classification. His former students Alexandre Rodrigues Ferreira (17561815), João da Silva Feijó (1760-1824), Joaquim José da Silva (1783-1808), Manuel Galvão da Silva (1750-?), and Manuel Arruda da Câmara (1752-1810) were involved in scientific journeys to Africa and Brazil. With minor modifications, they used the Linnaean system in their descriptions and memoirs.

Of all the scientific expeditions conducted within the Portuguese Empire, Alexandre Rodrigues Ferreira's nine-year journey to the Amazon region from 1782 to 1792 is the most wide-ranging and best-known (França 1922; Mittermeier 1992). Ferreira described and classified several animal and plant specimens that he shipped to the Ajuda Palace Gardens and Museum in Lisbon. However, the funding and the research effort invested in the expedition did not result in any publication. One of the reasons for this is that, during the Napoleonic wars, in 1808, a significant part of the collection, together with many of Ferreira's reports and memoirs, was expropriated by Étienne Geoffroy Saint-Hilaire (1772-1844) to the Muséum d'Histoire Naturelle in Paris (Simon 1983).

Manuel Galvão da Silva's expedition to Portuguese Goa was more successful in terms of publications. The species described in his Observations on the Natural History of Goa made in the year 1784 were all classified according to the Linnaean method (Silva 1862). It should, however, be noted that this work was much more limited in scope than the observations made in Brazil by Ferreira. The same can be said of João da Silva Feijó's Relation of the Cape Verde Islands (1783), in which the author uses the Linnaean system. However, this 
manuscript remained unpublished. ${ }^{13}$ Both Silva and Feijó sent herbaria to Lisbon, from Goa and the Cape Verde Islands, respectively (du Bocage 1862: 67). As a result of his expedition to Angola, Joaquim José da Silva also prepared a large herbarium of native plants that he sent to Lisbon (Simon 1983: 106).

The two major publications on the natural history of the Portuguese Empire can be attributed, not to trained naturalists, but to a Franciscan, José Mariano da Conceição Vellozo (1742-1811), and a Jesuit, João de Loureiro (1710-1791). Following his incursions into the region of Rio de Janeiro which lasted eight years, Vellozo finished his Flora Fluminese in 1790. The work comprises a description and classification of 1,640 species from the Brazilian flora, and is amply illustrated by Frei Francisco Solano. It was not published until thirty-five years later, when other floras of Brazil by foreign naturalists had already been printed (Vellozo [1825-1827] 1961). In any case, Brotero had a very critical view of Vellozo's work and considered that "in the present state of botany it would discredit the nation [...] that the title Fluminense was ambiguous and that its descriptions and drawings were very incomplete. Besides, the nomenclature of genera and species was erroneous and there were some families of plants lacking" (Fernandes 1947).

João de Loureiro was sent on a special mission to Cochinchina in 1742. Finding that missionary activities as such were not favourably regarded there, he entered the service of the King of Cochinchina as a mathematician and naturalist. Loureiro remained in Cochinchina for nearly thirty-six years, with the exception of one short interval. While in Cochinchina his chief place of residence was its capital city Hue. It was in the immediate vicinity of this city that he obtained many of his botanical specimens. In December 1777 Loureiro proceeded to Bengal, Pondicherry, Macao and Cantao. He stayed in this latter city for the next three years and it was during this period that Captain Thomas Riddel offered him the works Systema Naturae, Genera Plantarum and Philosophia Botanica by Linnaeus. As a result, Loureiro became a strict follower of Linnaeus. In exchange, he offered Riddel, who also put him in contact with Joseph Banks, various specimens that are now held at the British Museum.

Loureiro's Flora Cochinchinensis was completed in 1788 and published in 1790 with the sponsorship of the Royal Portuguese Academy of Sciences in Lisbon (Loureiro 1790). Its title is misleading in the sense that the work is not only dedicated to the flora of Cochinchina. It also includes a description and classification of several species from China, the Philippines, India and tropical

13. João da Silva Feijó, Itenerario filosofieo que contem a rellação das Ilhas de Cabo Verde pelo methodo epistolar, 1783, remains unpublished; Portuguese National Library, Codice 12984. 
East Africa. The work contains original descriptions of 185 new genera and nearly 1,300 species, of which about 630 were described as new. However, as E. D. Merrill has shown, Loureiro did not always fully understood the Linnaean system and the work contains various errors, such as descriptions of genera that had already been established by other authors under different names, attributions of species to genera to which they did not belong, descriptions of species as belonging to two, three or even four different genera, the lack of detailed descriptions of new genera and new species, and the lack and imperfection of herbaria (Merrill 1935). These kinds of shortcomings limited Loureiro's impact on the history of botany, and practically all the new genera and species described by Loureiro have been redescribed under other names. However, the innovative contribution of his work should not be forgotten, nor should the fact that it created enough of a sensation in European botanical circles for Carl Ludwig Willdenow (1765-1812) to issue, in 1793, a second annotated edition of Flora Cochinchinensis in Berlin (Loureiro 1793).

\section{Classification and the Muses}

The introduction of Linnaeus's ideas in Portugal was also achieved through poetry. In 1811, the distinguished poet Manuel Barbosa du Bocage dedicated a poem to the "Immortal Linnaeus", in which he described him not only as a "noble soul" and a "most gentle spirit", but also as a demigod (du Bocage 1811: Preface). However, the most complete homage to Linnaeus and to his method of classification was authored by a woman, the 4th Marquesa de Alorna (Leonor de Almeida de Portugal, 1750-1839). ${ }^{14}$ Owing to the persecution of her family by the Marquês of Pombal (1699-1782), she was imprisoned between 1758 and 1777 in the Convent of Chelas. It was here that she discovered her poetical inclinations, acquired a solid education in classical languages and developed a keen interest in scientific knowledge. After her release from prison, Leonor travelled to Madrid and then to Paris, where she had the opportunity to experience the atmosphere of the French salons. She lived for a few years in Vienna, where she was in touch with various members of the aristocracy and the cultural elite. Leonor was supportive of the Ancien Régime and strongly anti-Napoleonic. Fearing that the French would invade Portugal, she left for Britain in 1802. The French invasions took place between 1807 and 1811, but she remained in Britain for two more years. Her stay in Britain gave

14. On the Marquise of Alorna and her poetic work dealing with botany, see da Costa 2009. 
the future Marquesa de Alorna the opportunity to widen her intellectual horizons by coming into contact with contemporary authors, some of whose works she translated. She wrote the poem Botanical Recreations when she was living in Britain, a country that was well-known for the popularization of botany (Shteir 1996).

The Marquesa de Alorna was no mere amateur of botany. The poem Botanical Recreations and her translation of an English botanical work, Thomas Martyn's Letters on the Elements of Botany: Addressed to a Lady By the Celebrated J.J. Rousseau, Translated into English, with Notes, and Twenty-Four Additional Letters, Fully Explaining the System of Linnaeus (1785), testify to the contrary. The translation included additional notes which show her interest in and understanding of Linnaeus's system of classification. In one of the notes, she comments on the popularization of his system in Britain and Portugal:

The English or Portuguese student can only encounter advantages in the possession of many elementary books which explain terms to them in their own language. Linnaeus is translated into English. There is also the flora of Hudson, and the arrangement of Dr Wecthering which combine the English terms with those of Linnaeus, Dr Wardelly, Professor Brotero, Gresley and the Count Hoffmannsegg it is they who have introduced botany into Portugal. The Abbé Correia has written nothing on this subject as yet. ${ }^{15}$

The Botanical Recreations were written within the tradition of the didactic poem, a genre widely used during the late eighteenth and early nineteenth centuries in the popularization of botany. The poem is dedicated to Portuguese women and especially to the younger female generations. The Dedicatory Epistle invited them to study nature and to develop their passion for botany. In this invocation, the Marquesa of Alorna made explicit reference to the incomparable Linnaeus and also to the aforementioned Portuguese naturalists Brotero and Correia da Serra:

What luxury! What wealth! If Flora bids

You open the Linnaean Temple!

If tireless Zephyrs whirling,

With perfumed wings unfurling,

Welcome you with scents of flowers!

If Brotero and Correa invite you

To explore Nature in glade and valley

As well as explore gardens! If they name

You priestesses of these floral Temples! (Alorna 1844: 8-9)

15. Arquivos Nacionais Torre do Tombo (Lisbon), Collection "Casa de Fronteira e Alorna", Codice 146, note v. This is an undated manuscript. 
Linnaeus and his system of classification based on sexual characteristics had a central place in the Marquesa de Alorna's Botanical Recreations:

Astonished the Wise, who long believe

Linnaeus converses with the Deity:

Or that sentient plants confide to him

Their loves in florid eloquence (Alorna 1844: 9)

[...]

Linnaeus is the Polymarch of their army

And knows the laws of mating

And like the General whose soldiers

Places on the battlefield; the orders and species of plants

Linnaeus glimpsed without confusion

That ray of light that all things illuminates

And arcanas perceived in benign revelation (Alorna1844: 46).

In the Botanical Recreations, the Marqusa makes direct reference to the sexual connotations implicit in the Linnaean system of classification and even declares that "polygamy is necessary" in the plant kingdom (Alorna1844, vol. 4: 93). However, allusions of this kind do not have a central place in the text. Instead, emphasis is given to personified narratives on each plant, which lead to moral teachings. Thus, the description of the Mimosa pudica (the sensitive plant), whose leaves close in upon themselves and droop when touched, an example of the Linnaean class Polygamia, is used as a model for the behaviour of young women. In fact, the retraction of the plant when touched is used as a metaphor for the necessary retraction of women from a gender-biased society:

This plant is worthy of the Muses,

As it speaks to the heart and mind.

I believe a nymph lies transformed

Within her, whose pain, modesty and brio

Opened the dark entrance to Orcus

What a modest maid, the Sensitiva

She recoils from the profane touch

Like a virgin, frightened by a simple touch,

She retracts from any touch, discolours and fades.

Crown yourselves with her, choose her as your guide:

To escape is to triumph for our sex (Alorna1844: 102).

The Marquise described Linnaeus as "the botanical genius", "with a seat in heaven" (Alorna 1844: 22). Nevertheless, she stated her awareness of the limitations of his system of classification, especially its degree of artificiality: 
The Species is certain and inalterable

[...]

It is within Nature;

But further divisions are mind-designed

Methods diverse which memory holds

In orders, genera and systems

[...]

Of these species Botanists composed

New groups, designating them with the name

Of genus and genera they sought

(even Linnaeus) to discover them in Nature

But it is time and observation which all discloses

And it is before truth that conjecture ceases (Alorna 1844: 54).

Moreover, she asserted in the poem that there is more to botanical knowledge than classification:

To know the name of plants does not suffice

[...]

Analogies, habit, character

Lead Science to the greatest heights (Alorna 1844: 21).

Neither is Linnaeus the only foreign naturalist mentioned in the Botanical Recreations. The poet also stressed the contributions of John Ray (1627-1705), Joseph Pitton Tournefort (1628-1705) and Antoine Laurent de Jussieu (17481836) to the progress of this subject. Besides, Rousseau's Elementary Letters on Botany are presented as one of the most useful works for the improvement of botanical knowledge. Brotero and Correia da Serra, too, are praised in the poem. Despite his contribution to the diffusion of botany in Portugal, however, Vandelli's name is absent from the Botanical Recreations. This absence is probably related to the fact that Vandelli collaborated with the French during the French invasions and that the Marquise of Alorna was strongly anti-Napoleonic.

The Botanical Recreations were written between 1810 and 1813, but were only published in the first volume of the Marquesa de Alorna's Poetical Works in 1844. The printed version differs from the original in the notes added by the naturalist Caetano Bordão, together with those of the editor, Carlos Manuel Soye. ${ }^{16}$ These notes expand the botanical knowledge provided by the work and include two tables on the Linnaean system of classification, taken directly from Brotero's Compendium of Botany (Pina 1953: 22).

It should also be noted that the fact that the Botanical Recreations were only published in 1844 does not imply that the work, or at least part of it, did not have

16. Only the notes to the first Canto were written by the Marquise of Alorna. 
an audience before this date. It is known that various letters circulated publicly among the upper classes. Excerpts from the Botanical Recreations might have been diffused in this way. The circulation of copies of the Botanical Recreations among a restricted group of friends was probably another way in which the work was disseminated. We should also take into account that the salons organized by the Marquesa de Alorna and other members of her social network are likely to have aided the diffusion of the work. It is not strange, therefore, that although the Marquesa de Alorna published very few works during her lifetime, her literary skills were known even abroad. The fact that women writers from this period published very few works should not conceal their very important role as intellectual producers and mediators of new knowledge, including in the field of botany.

\section{Conclusion}

We have seen in this essay that the introduction of the Linnaean system of classification in Portugal was intimately connected with the political context of the time. It was the reform of the University of Coimbra promulgated by the Marquis of Pombal that enabled the inclusion of the Linnaean programme of classification within the university curriculum. The history of the first Portuguese flora by Brotero also reveals how the scientific value of the enterprise cannot be divorced from nationalist and political questions.

Educational, political and economic reforms were especially interrelated when the description and exploration of overseas territories were at stake. On the one hand, it is no coincidence that the majority of the naturalists educated at the new reformed University of Coimbra were employed by the state on scientific voyages to the overseas territories, with a view to defining a strategy for the optimal allocation of available resources. On the other hand, it appears that the history of botany and the Portuguese Empire seems to be a history of missed opportunities. The two major floras that were produced had various shortcomings, and one of them does not relate exclusively to the Portuguese Empire. It should also be noted that the task of producing a major natural history of Brazil would have a required a much larger number of trained naturalists, as well as a greater political and financial commitment from the state.

Finally, the diffusion of the Linnaean system of classification was celebrated in various ways, including poetry. Moreover, unlike other botanical works, the poem Botanical Recreations specifically invited women to join in this celebration by participating in the pleasures of contemplating and understanding the order of nature. 


\section{Acknowledgements}

I would like to thank Fernando Mascarenhas for allowing me to consult some of the original manuscripts at the Fundação das Casas de Fronteira e Alorna; Francesca Rayner for her linguistic revision of this essay and translations of original quotations; and Christopher Damien Auretta for his kind assistance with translations of excerpts from the poem Botanical Recreations. My thanks also go to the librarians of the Arquivos Nacionais Torre do Tombo, Lisbon, and the Biblioteca Nacional, Lisbon, for their kind assistance. In addition, I would like to thank Professor Britt-Louise Gunnarsson for her very helpful suggestions in the revision of the manuscript.

\section{References}

Alorna, Marquesa de

1844 Recreações Botânicas [Botanical recreations]. In Obras Poéticas [Poetical works], 4th vol. Lisboa: Imprensa Nacional.

Brigola, João Carlos

2003 Colecções, Gabinetes e Museus em Portugal no século XVIII [Collections, cabinets and museums in eighteenth-century Portugal]. Lisboa: Fundação Calouste Gulbenkian, Fundação para a Ciência e a Tecnologia.

Brotero, Félix Avelar

1788 Compêndio de Botânica [Compendium of Botany]. Lisboa: Casa de Paulo Martins.

Cardoso, José Luís

1990-91 Introdução [Introduction]. In J. L. Cardoso (ed.), Memórias económicas da Academia Real das Ciências de Lisboa, para o adiantamento das artes, e da indústria em Portugal, e suas conquistas (1789-1815) [Economic memoirs of the Royal Academy of Sciences of Lisbon for the improvement of the arts and industry of Portugal and its conCardoso, José Luís (ed.) quests], xvii-xxxiii. Lisboa: Banco de Portugal.

1994 Memórias económicas da Academia Real das Ciências de Lisboa [Economic memoirs of the Royal Academy of Sciences of Lisbon] (17891815). Lisboa: Banco de Portugal.

Cardoso, José Luís (ed.)

2003 Memórias de História Natural, Domingos Vandelli [Memoirs on natural history by Domingos Vandelli]. Porto: Porto Editora. 
Cardoso, José Luís

2003 From natural history to political economy: the enlightened mission of Domenico Vandelli in late eighteenth-century Portugal. Studies in the History and Philosophy of Science 34: 781-802.

Carvalho, Rómulo de

1987

A história Natural em Portugal no século XVIII [Natural history in eighteenth-century Portugal]. Lisboa: Instituto de Cultura e Língua

Carvalho, Rómulo de Portuguesa.

2001 de História do Ensino em Portugal [The History of Teaching in Portugal]. Lisboa: Fundação Calouste Gulbenkian.

Castel-Branco, Cristina

2004 Félix de Avelar Brotero: botaniste portugais (1744-1828). Paris: Centre Culturel Calouste Gulbenkian.

da Costa, Palmira Fontes

2009 Women and the Popularisation of Botany in Early Nineteenth-Century Portugal: The Marquesa de Alorna's Botanical Recreations. In: Faidra Papanelopoulou, Agustí Nieto-Galan and Enrique Perdiguero (eds.), Popularisation of Science and Technology in the European Periphery. Aldershot: Ashgate, 43-63.

du Bocage, J. V. Barbosa

1862 Instrucções Prácticas sobre o Modo de Colligir, Preparar e Remeter Produtos Zoologicos para o Museu de Lisboa [Practical instructions on the best way to collect, prepare and send zoological specimens to the Lisbon Museum]. Lisboa: Imprensa Nacional, 1862.

du Bocage, Manuel Maria Barbosa

1811 Aos Manes do Immortal Linné [To the immortal Linnaeus], Preface. In Manuel Maria Barbosa du Bocage (ed.), O Consorcio das Flores de Lacroix [The Marriage of Flowers by Lacroix]. Rio de Janeiro: Impressão Régia.

Faria, Miguel

2001 A Imagem Útil [The useful image]. Lisboa: Universidade Autónoma de Lisboa.

Fernandes, Abílio

1947 Quatro cartas inéditas de Brotero para o Conde da Barca [Four unknown letters from Brotero to the Count of Barca]. Revista da Faculdade de Ciências da universidade de Coimbra 16: 90-120.

Fernandes, Abílio

1986 História da Botânica em Portugal até finais do século XIX [History of Portuguese botany up to the end of the nineteenth century]. In História e Desenvolvimento da Ciência em Portugal [History of the development of science in Portugal], 2nd vol., 851-916. Lisboa: Academia das Ciências de Lisboa. 
Fernandes, Abílio

1988

Relance sobre a vida e a obra de Félix de Avelar Brotero [A brief glance at the life and work of Félix de Avelar Brotero]. Anuário da Sociedade Broteriana 54: 1-13.

França, Carlos

1992

Doutor Alexandre Rodrigues Ferreira (1756-1815): História de uma missão científica ao Brasil no século XVIII (Doctor Alexandre Rodrigues Ferreira (1756-1815): History of a scientific mission to Brazil in the eighteenth century]. Coimbra: Imprensa da Universidade.

Henriques, Júlio

1882

Felix de Avellar Brotero. Plutarcho Portuguez 2: 41-48.

Henriques, Júlio

$1889 \quad$ Felix de Avellar Brotero, O Instituto 37: 364-389.

Link, Heinrich Friedrich

[1801] 2005 Notas de uma viagem a Portugal e através de França e Espanha [Notes on a voyage through Portugal, France and Spain]. Lisboa: Biblioteca Nacional.

Linnaeus, Carolia

1793 Systema naturae, Decima Tercima Reformata Jo: Frid. Gmelin, Editio in Lusitania Prima. Conimbricae: Typis Academicis.

Lopes, Maria Margaret, Clarete Paranhos da Silva, Silvia Fernanda de M. Figueirôa, and Rachel Pinheiro

2005

Scientific Culture and Mineralogical Sciences in the Luso-Brazilian Empire: The Work of João da Silva Feijó (1760-1824) in Ceará. Science in Context 18: 201-224.

Loureiro, João de 1790

Flora cochinchinensis: sistens plantas in regno Cochinchina nascentes: quibus accedunt aliae observatae in Sinensi Imperio, Africa Orientali, Indiae que locis variis omnes dispositae secundum systema sexuale Linnaeanum. Lisboa: Typis et expensis Academicis.

Loureiro, João de 1793

Flora Cochinchinensis, sistens Plantas in regno Cochinchina nascentes; quibus accedunt aliae observatae in Sinensi Imperio, Africa Orientali, Indiaeque locis variis... denuo in Germania edita cum notis Caroli Ludovici Willodenow. Berolini: Haude et Spener.

Luisier, A. 1944

Félix Avelar Brotero. Brotéria 13:145-158.

Melli, G. F. 1966 Un italiano in Portugallo - Domenico Vandelli. Estudos Italianos em Portugal, 26: 2-18.

Merrill, E. D. 1935

A commentary on Loureiro's Flora Cochinchinense. Transactions of the American Philosophical Society 24:1-45. 
Mittermeier, Russell

1992 Philosophical journey: a rediscovery of the Amazon: 1792-1992. Rio de Janeiro: Index.

Oswaldo, Munteal Filho

Todo um mundo a reformar: intelectuais, cultura ilustrada e estabelecimentos científicos ilustrados em Portugal e no Brasil, 1779-1880 [An entire world to reform: Intellectuals, enlightened culture and scientific establishments in Portugal and Brazil, 1779-1880]. Anais do Museu Histórico Nacional, 29: 87-108.

Palhinha, Ruy Telles

1944 O sistema sexual broteriano [The Broterian sexual system]. Boletim da Sociedade Broteriana 19: 75-93.

Real Academia das Ciências de Lisboa

1781

Breves instrucções aos correspondentes da Academia das Sciencias de Lisboa sobre as remessas dos produtos e noticias pertencentes à historia da natureza para reformar hum Museo Nacional [Brief instructions to the correspondents of the Lisbon Academy of Sciences concerning the ways of sending specimens and news on natural history for the reform of the National Museum]. Lisboa: Regia Officina Typographica.

Shteir, Ann B.

1996 Cultivating Women, Cultivating Science: Flora's Daughters and Botany in England, 1760 to 1860. Baltimore: Johns Hopkins University Press.

Silva, Manoel Galvão da

$1862 \quad$ Observações sobre a história natural de Goa feitas no anno de 1784 [Observations on the natural history of Goa made in the year 1784]. Nova-Goa: Imprensa Nacional.

Simões, Ana, Maria Paula Diogo, and Ana Carneiro

2006 Cidadão do Mundo: Uma Biografia Científica do Abade Correia da Serra [Citizen of the world: The biography of Correia da Serra]. Porto: Porto Editora.

Simon, W. J.

$1983 \quad$ Scientific Expeditions in the Portuguese Overseas Territories (17831808). Lisboa: Instituto de Investigação Científica Tropical.

Vandelli, Domenico

1788 Diccionario dos termos technicos de Historia Natural, extrahidos das obras de Linneo [Dictionary of technical terms of natural history extracted from the works of Linnaeus]. Coimbra: Real Officina da Universidade.

Vellozo, José Mariano da Conceição

[1825-27] 1961 Flora fluminensis. Rio de Janeiro: Arquivo Nacional. 
